\title{
The herpetofauna of Faure Island, Shark Bay, Western Australia
}

\author{
Ken Aplin', Steve Donnellan ${ }^{2}$ and John Dell ${ }^{3}$ \\ Australian National Wildlife Collection, CSIRO Division of Sustainable Ecosystems, \\ PO Box 284, Canberra City, ACT 2604, Australia; E-mail: ken.aplinencsiro.au \\ 2Evolutionary Biology Unit, The South Australian Museum, North Terrace, \\ Adelaide, SA 5000, Australia \\ Department of Environment and Conservation, PO Box K822, \\ Perth, WA 6842, Australia
}

\begin{abstract}
The currently recorded Faure Island herpetofauna comprises 24 species of reptile. This is a strict subset of the more diverse herpetofauna recorded from adjacent Peron Peninsula. We describe the broader geographic distributions and habitat associations of each species, and discuss the biogeography of the island herpetofauna in the context of the Carnarvon Basin biogeographic region. The reduced island diversity is presumably due to a combination of lesser sampling effort and 'drop out' extinctions following drowning of the continental shelf and severance of the island around 6500 years ago.
\end{abstract}

Key words: Shark Bay World Heritage Property, herpetofauna, reptiles, 'drop out' extinction, continental shelf

\section{INTRODUCTION}

The Shark Bay World Heritage Area (SBWHA) is a landscape of outstanding biotic diversity. Located at latitude $26^{\circ} \mathrm{S}$ along the Western Australian coastline, it falls within the Carnarvon Basin biogeographic region (Thackway and Cresswell 1995) and comprises a complex of peninsulae and associated major islands of which Faure Island, with an area of 5,816 hectares, is the second largest (exceeded only by Dirk Hartog Island). The high biodiversity in the area reflects its location at the contact zone between two major Australian biogeographic provinces - those of the temperate southwest and the arid inland - as well as a complex geomorphic history related to its position near the inland margin of a broad continental shelf (Kendrick et al. 1991; Wyrwoll et al. 2000).

Faure Island was a pastoral lease from 1873 and was purchased by the Australian Wildlife Conservancy (AWC) in 2000. Biological surveys were conducted in May-June 2000 ahead of its development for conservation. The purpose of this paper is to summarize current knowledge of the herpetofauna of Faure Island, including new information gathered during a field survey in MayJune 2000. We also explore the biogeographic significance of the Faure herpetofauna in the context of the wider Camarvon Basin biogeographic region (Thackway and Cresswell 1995; Burbidge et al. 2000).

\section{ENVIRONMENT}

Faure Island is located in Disappointment Reach, on the eastern side of Peron Peninsula, and is centred on $25^{\circ} 50^{\prime} \mathrm{S}$ and $113^{\circ} 53^{\prime} \mathrm{E}$ (Figure 1). The island rises to a maximum of $26 \mathrm{~m}$ above sea level and comprises two north-south trending dune ridges, with lower dunes and swales down the central axis. Surface sediments are predominantly mobile to weakly consolidated red sands derived from the Peron Sandstone but habitat diversity is created by cliffs along the western margin of the island, by local outcrops of shelly limestone and calcrete, and by a prograded Holocene dune complex of white sands along the northern, eastern and southern margins. Numerous small birridas (deflational salt pans) and saline marshes further extend the habitat complexity of the island.

Faure Island experiences an arid climate. Rainfall records from Hamelin Pool (2625'S; 114 11'E), immediately to the south, average $210 \mathrm{~mm}$ per year, with rainfall divided between winter fronts and summer cyclonic rains. Average daily maximum temperatures for the winter months are $21^{\circ}-25^{\circ} \mathrm{C}$ and for the summer months are $30^{\circ}-35^{\circ} \mathrm{C}$

Beard (1976) identified two vegetation systems on the island and included it in his Eremaean (Desert) Phytogeographical Region (Beard 1980). The southem third of the island was mapped as Acacia ligulata $X$ rostellifera thicket (included in the Denham Vegetation System), while the northern 


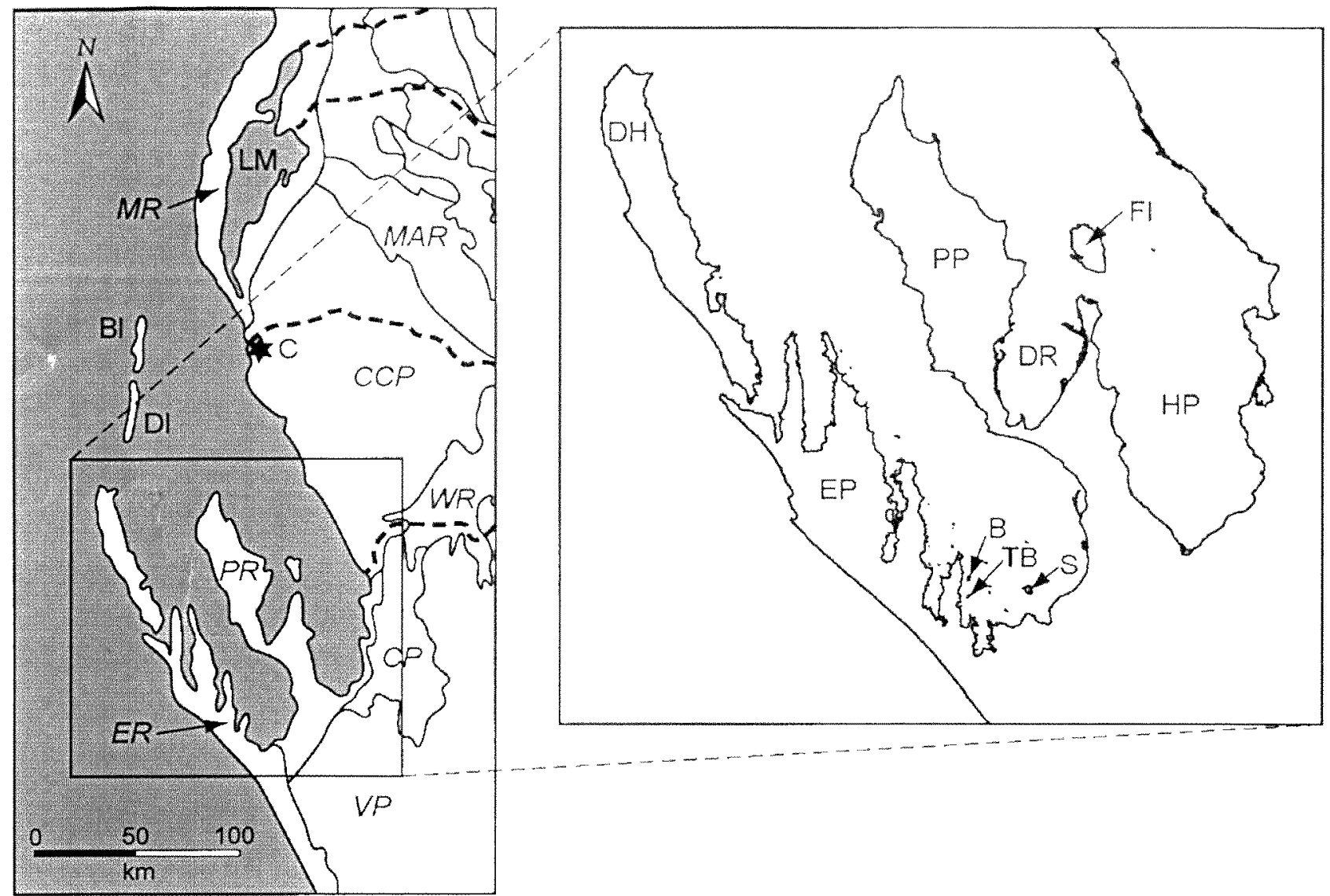

Figure 1 Location map showing geographic features and geomorphic regions (after Hocking et al. 1987) mentioned in the text. Geographic features: B-Baudin Island; BI-Bernier Island; C-Carnarvon Townsite; DH-Dirk Hartog Island; DI-Dorre Island; DR-Disappointment Reach; EP-Edel Land Peninsula; FI-Faure Island; HP-Hamelin Pool; LM-Lake Macleod; PP-Peron Peninsula; S-Salutation Island; TB-Three Bays Island. Geomorphic Regions: $C C P$-Carnarvon Coastal Plain; $C P$-Carbla Plateau; ER-Edel Region; $M A R$-Mardathunna Region; $M R$-Macleod Region; PR-Peron Region; VP-Victoria Plateau; WR-Wooramel region.

portion mapped as Acacia ramulosa scrub with scattered samphire shrublands in the birridas and saline marshes (included in the Peron Vegetation System). Keighery and Muir (2008) identified five plant communities on the island of which Acacia shrublands occupy by far the largest area, followed by roughly equal areas of samphire, spinifex grasslands (on coastal dunes), Atriplex shrublands (around birridas) and mangrove communities. The north of the island supports small stands of mallee shrubland over a dense grassland of Triodia plurinervata. The vascular flora is a subset of that recorded from Peron Peninsula (Keighery et al. 2000).

Hocking et al. (1987) included Faure Island in their Peron Region, otherwise represented by the adjacent Peron Peninsula and the southern and eastern margins of Disappointment Reach. This region is characterised by an undulating topography (to $30 \mathrm{~m}$ ) of stabilized, unconsolidated red sand dunes of late Pleistocene age, overlying an older, consolidated dune complex (the Peron Sandstone) laid down during earlier Quaternary times. Peron Region is encircled by Edel Region (including Edel Peninsula) to the west, Victoria
Plateau to the south, and Carbla Plateau and Carnarvon Coastal Plain to the east (Figure 1).

\section{HISTORY OF HERPETOFAUNAL COLLECTING}

There was no information on the herpetofauna of Faure Island until May 1959 when W. H. Butler visited the island and collected five species (see Table 1). A sixth species was collected by K. D. Morris in September 1989. Greg Harold and Angela Sanders visited Faure Island in November 1989 during a search for threatened native mammals in the Shark Bay region and added an additional nine reptile species. All specimens collected during these prior visits to Faure Island, representing a total of 15 species, are lodged in the collections of the Western Australian Museum (identified by $R$ prefix).

During the May-June 2000 and February 2002 surveys of Faure Island (Schmitz and Richards 2008 ), reptiles were taken in traps, especially in pit traps, set by team members for mammals and invertebrates. Brief descriptions of trap sites are given in Schmitz and Richards (2008). Specimens were also collected by hand especially during 
Table 1 Summary of collections of reptiles from Faure Island with associated voucher specimens (W.A. Museum collection).

Collector: W. H. Butler, 12-13/5/1959
Ctenophorus reticulatus
Gehyra variegata
Heteronotia binoei
Menetia greyii
Simoselaps littoralis
Collector: K. D. Morris, 20/9/1989
Morethia lineoocellata

Collector: G. Harold, 23-26/11/1989

Diplodactylus pulcher

Heteronotia binoei

Lucasium squarrosum

Nephrurus levis occidentalis

Ctenotus fallens

Lerista connivens

Lerista elegans

Lerista lineopunctulata

Lerista varia

R13127
R13141, R13262, R98204-10
R13130/3, R78922-3
R13193
R23636

R103255-6

R103937

R103938/83

R103940

R103936

R103935

R103941

R103975, R103987-8

R103939

R104251-3

Collector: AWC Biological Survey, 25/05/2000- 1/06/2000

Ctenophorus reticulatus $\quad$ R141452/6

Pogona m. minor

Gehyra variegata

Heteronotia binoei

Lucasium squarrosum

Nephrurus levis occidentalis

Strophurus strophurus

Cryptoblepharus sp. plagiocephalus?

No voucher; sight record

R141460-1, 67/9, 89-90

R141453-4/9, 71

R141462

R141450, 88

R141457, 72, 95

Ctenotus fallens

Lerista connivens

No voucher; sight record

Lerista elegans

Lerista lineopunctulata

R141451/5-6, 64-5, 70, 141698

R141487

R141474-5, 83/6, 95-6

R141493

R141492

Lerista macropisthopus

R141692

Lerista micra

R141463

Lerista planiventralis

$\mathrm{R} 141482 / 5,73,91$

Lerista praepedita

Lerista varia

R41494

Menetia greyii

Morethia lineoocellata

Simoselaps littoralis

Antaresia stimsoni

R141484, 93

R141458, 68, 94/7

R141476-7, 96

No voucher; captured and released

AWC Opportunistic surveys 2000-2005

Eremiascincus sp.

Recorded in cat gut

Ctenotus schomburgkii

Trapped and released, photo

Varanus gouldii

Frequently recorded, photos

nocturnal head torching. Most of these specimens were identified on site, recorded and released. Some voucher specimens were retained and lodged in the collections of the Western Australian or South Australian Museums, along with frozen tissues suitable for molecular analyses. In addition, three species were identified by sightings and not collected. During this survey, all but one of the reptiles recorded on the island previously were recorded again. The exception is Diplodactylus pulcher. However, the survey recorded eight species for the first time, bringing the total then recorded from Faure Island to 22 species.

A feral cat trapping programme in September 2000 (Algar and Angus 2008) revealed five reptile species as cat prey, including one additional species for Faure Island (Eremiascincus sp.). An additional species (Ctenotus schomburgkii) was trapped in July 2005, making a final tally of 24 species for Faure Island.

Several of the species recorded on Faure Island belong to groups requiring further taxonomic study. These are indicated here by the designation 'c.f.' 
The herpetofauna of the wider Carnarvon Basin biogeographic region was inventoried by Storr and Harold (1978, 1980, 1984) and more recently subjected to systematic, quadrat-based sampling as part of a regional biological survey (McKenzie et al. 2000). A comprehensive review of the regional herpetofauna was undertaken in conjunction with this survey by Aplin, M.A Cowan and M. Adams (unpublished report), including genetic analyses of selected taxa. We draw heavily on this report for information on regional distributions and for some taxonomic considerations.

\section{HERPETOFAUNA OF FAURE ISLAND AND SURROUNDING AREAS}

The currently documented herpetofauna of Faure Island, as listed in Tables 1-2, includes 21 confirmed reptile species and three others recorded as sightings only (indicated by ' $s$ '). No frogs are known to occur on the island. Scincidae (skinks) is the most speciose family (13 spp.), followed by Diplodactylidae (clawed geckos; 3 spp.) and Gekkonidae and Agamidae (padded geckoes and dragons, respectively; 2 spp. each). Caphodactylidae (knob and leaftailed geckos), Varanidae (goannas), Boidae (pythons) and Elapidae (front-fanged snakes) are each represented by a single species.

Peron Region has a recorded herpetofauna of 65 reptile species (Table 2 ). No frogs are recorded from this extremely arid landform. Scincids (25 spp.) and gekkotans (includes the three gecko families above; 10 spp.) are similarly well-represented in this region, but elapids ( 8 spp.) are proportionally more diverse. Two additional families are also represented, Typhlopidae (blind snakes) and Pygopodidae (legless lizards), the latter of which is well-represented with nine species.

All of the reptile species found on Faure Island probably also occur on Peron Region. A possible exception is Crytoblepharus plagiocephalus, recorded as a possible sighting only on Faure Island. Regionally, this species is present on Edel Region and adjacent western margin of the Victoria. Plateau, extending onto Dirk Hartog and Dorre Islands. In Peron Region it is replaced ecologically by a form of $C$. carnabyi. The two species are morphologically very alike and without a voucher specimen, we cannot be certain as to the identity of the Faure Island Cryptoblepharus.

Lucasium squarrosum was recorded on Faure Island in 1989 and 2000. A recently collected sample (R141462) was included in a genetic study by Pepper et al. (2006), thereby confirming its genetic identity to other local populations of $L$. squarrosum. This taxon is not recorded from Peron Peninsula but is widespread in the Carnarvon Basin region. Most records come from open Acacia scrub or chenopod shrubland on heavy red soils.
Edel Region has a recorded herpetofauna of 52 reptiles and three frogs including the Northern Sandhill Frog, Arenophryne rotunda (Table 2). Six of the species found on Faure Island are absent from Edel Region. This includes a python (Antaresia stimsoni), three diplodactylid geckos (Diplodactylus pulcher, L. squarrosum, Strophurus strophurus) and a small litter-dwelling skink (Lerista micra). In addition, the fossorial skink Lerista planiventralis is represented by a different subspecies (nominate on Edel Region; decora on. Faure Island).

Carnarvon Coastal Plain, on the eastern margin of Disappointment Reach, supports a recorded herpetofauna of 57 reptile and 7 frog species (Table 2). Four of the species found on Faure Island are absent from the Carnarvon Coastal Plain. This includes three skinks (Cryptoblepharus sp., Lerista varia, Menetia greyii) and one elapid (Simoselaps littoralis). In addition, the fossorial skink $L$. planiventralis is represented by a different subspecies (nominate on Carnarvon Coastal Plain; decora on Faure Island).

Dirk Hartog Island supports a herpetofauna of 24 reptiles and one frog (Table 2). The species list is similar to that of Edel Region but with a number of significant differences. Notable absences from Dirk Hartog include Furina ornata, Christinus marmoratus and Lucasium alboguttatum. Several taxa found on Dirk Hartog are absent from Edel Region. The most notable are Antaresia stimsoni, which is present on Bernier and Dorre Islands and Peron Peninsula, and occurs throughout the inland part of the Carnarvon Basin biogeographic region; and Delma butleri, which also occurs at Cape Cuvier and in the northern part of the Carnarvon Basin biogeographic region.

Bernier and Dorre Islands have a combined herpetofauna of 31 reptile species (Table 2). All but one of these are recorded from Bernier Island, with a reduced suite of 17 species known from Dorre Island, presumably reflecting a lesser sampling effort. These islands share a variety of typically southern species with Dirk Hartog and/or the Edel Region, including Strophurus s. spinigerus, Nephrurus milii and Ramphotyphlops australis; these taxa do not occur on Peron Peninsula or on the mainland to the north. In contrast, several species are shared exclusively with the Cape Cuvier region (Strophurus rankini and Rankinia parviceps) or with the inland Carnarvon Basin including Peron Peninsula (Strophurus strophurus, Diplodactylus klugei). The presence of Menetia surda cresswelli on Bernier Island provides a unique link with Peron Peninsula and inland sand plain habitat on the Victoria Plateau south to the Yuna district; while the population of Egernia multiscutata on Bernier Island is spectacularly disjunct, the nearest population being on coastal sands between 
Table 2 Comparison of the Faure Island herpetofauna with that recorded from various other islands in the Shark Bay World Heritage Area and on adjacent land units of the Carnarvon basin biogeographic region (Burbidge et al. 2000, based on Hocking et al. 1987).

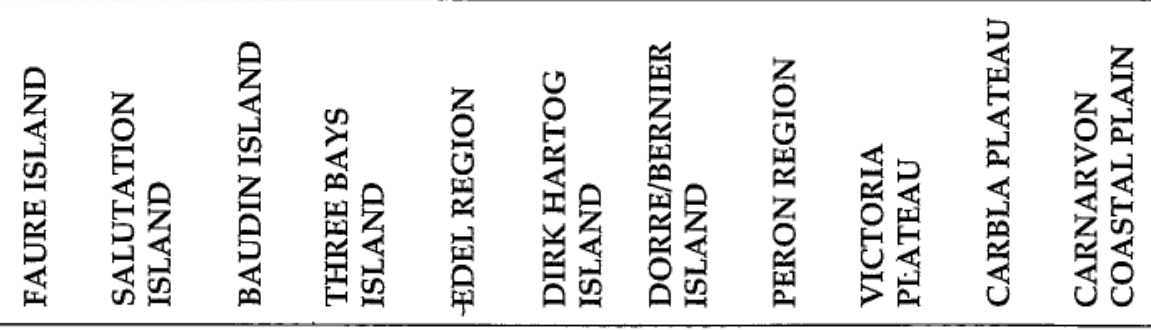

\section{Hylidae}

Cyclorana maini

Cyclorana platycephala

Litoria rubella

\section{Myobatrachidae}

Arenophryne rotunda

Opisthodon spenceri

Neobatrachus fulvus

Neobatrachus pelobatoides

Neobatrachus sutor

Neobatrachus wilsmorei

Pseudophryne guentheri

Pseudophryne occidentalis

\section{Chelidae}

Chelodina steindachneri

\section{Typhlopidae}

Ramphotyphlops australis

Ramphotyphlops gxypus

Ramphotyphlops hamatus

Ramphotyphlops leptosoma

Ramphotyphlops waitii

\section{Boidae}

Antaresia stimsoni

Aspidites ramsayi

\section{Elapidae}

Brachyurophis approximans

Brachyurophis f. fasciolata

Brachyurophis semifasciata

Demansia calodera

Demansia psammophis cupreiceps

Demansia psammophis reticulata

Furina ornata

Neelaps bimaculata

Parasuta monachus

Pseudechis australis

Pseudonaja modesta

Pseudonaja nuchalis

Simoselaps bertholdi

Simoselaps littoralis

Suta fasciata

\section{Agamidae}

Amphibolurus longirostris

Caimanops amphiboluroides

Ctenophorus maculatus badius

Ctenophorus maculatus maculatus

Ctenophorus nuchalis

Ctenophorus reticulatus

Ctenophorus rubens 
Table 2 (cont.)

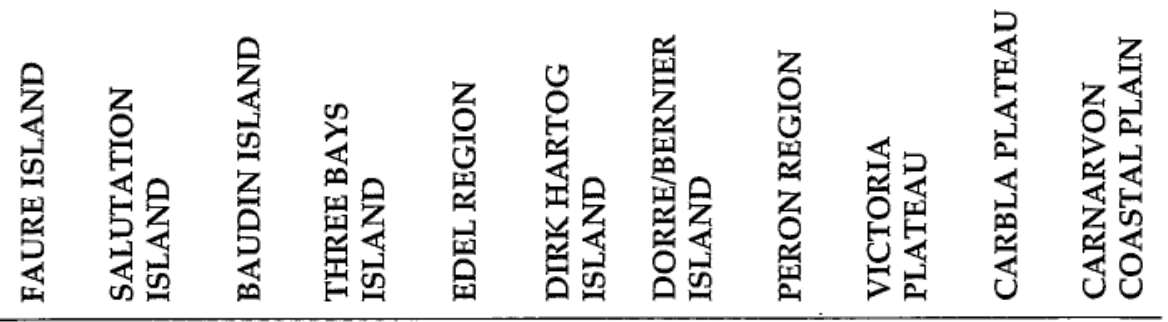

Ctenophorus scutulatus

Moloch horridus

Pogona minor minor

Rankinia adelaidensis adelaidensis

Rankinia butleri

Rankinia parviceps

Gekkonidae

Christinus marmoratus s.1.

Gehyra punctata

Gehyra variegata

Heteronotia binoei

Diplodactylidae

Crenadactylus ocellatus

Diplodactylus conspicillatus

Diplodactylus klugei

Diplodactylus ornatus

Diplodactylus pulcher

Lucasium alboguttatum

Lucasium squarrosum s.l.

Nephrurus levis occidentalis

Nephrurus milii

Rhynchoedura ornata

Strophurus michaelseni

Strophurus rankini

Strophurus s. spinigerus

Strophurus strophurus

Pygopodidae

Aclys concinna major

Aprasia haroldi

Aprasia smithi

Delma australis

Delma butleri

Delma fraseri

Delma nasuta

Delma tincta

Lialis burtonis

Pletholax gracilis edelensis

Pygopus lepidopodus

Pygopus nigriceps

S+

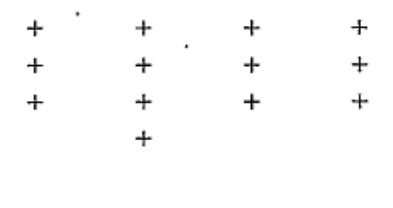

Scincidae

Cryptoblepharus carnabyi A

Cryptoblepharus carnabyi B

Cryptoblepharus plagiocephalus s.l. S

Ctenotus alleni

Ctenotus australis

Ctenotus fallens

Ctenotus leonhardii

Ctenotus mimetes

Ctenotus pantherinus ocellifer

Ctenotus pantherinus pantherinus

Ctenotus schomburgkii

Ctenotus severus

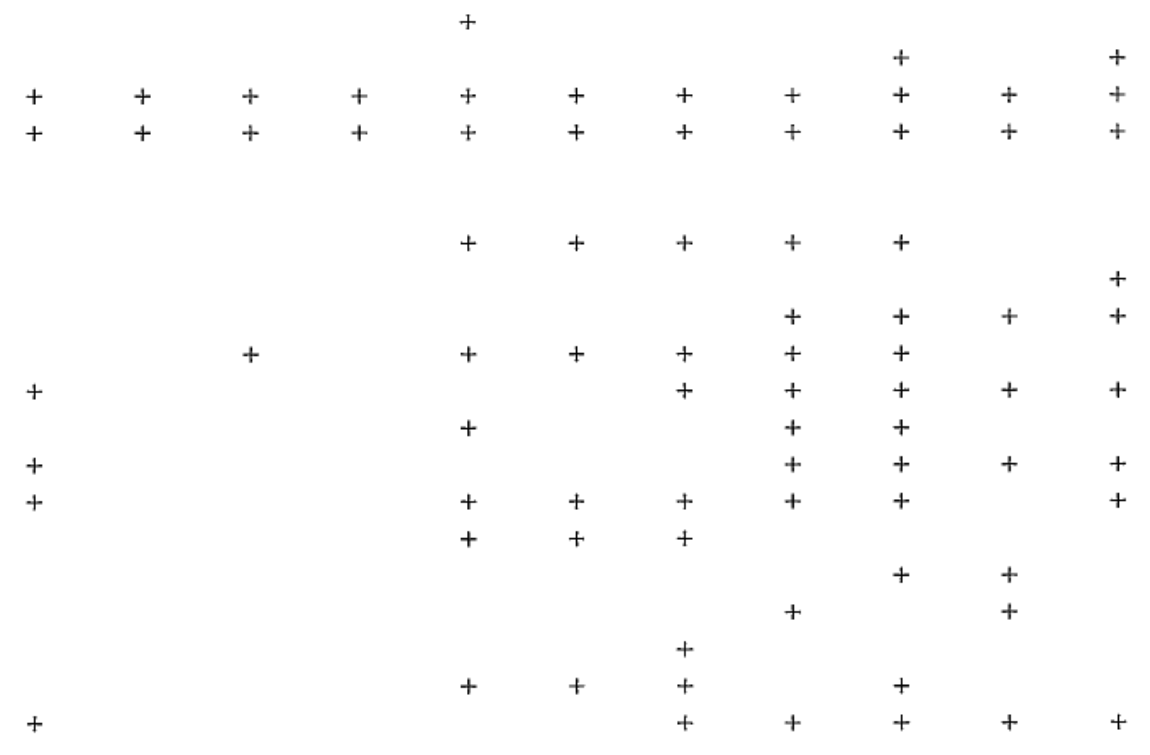


Table 2 (cont.)

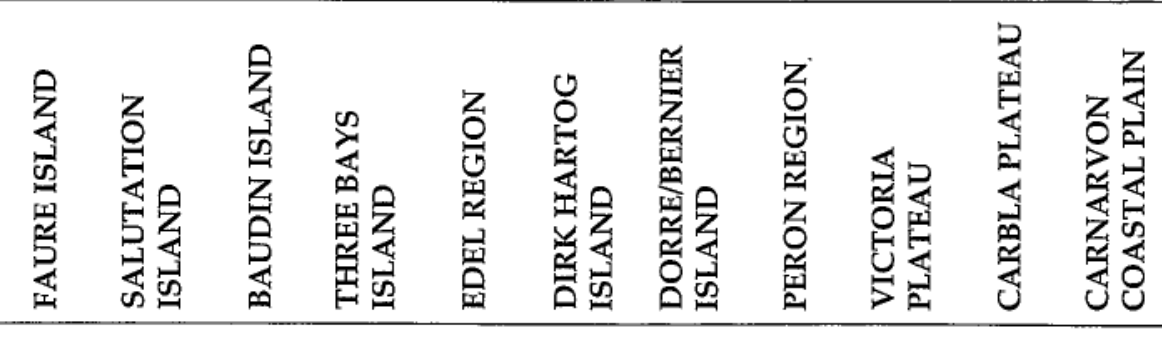

Ctenotus uber uber

Ctenotus youngsoni

Ctenotus zastictus

Cyclodomorphus celatus

Egernia depressa

Egernia inornata

Egernia kingii

Egernia multiscutata

Egernia stokesii badia

Egernia stokesii stokesii

Eremiascincus richardsonii

Lerista connivens

Lerista elegans

Lerista gascoynensis

Lerista humphriesi

Lerista kendricki

Lerista lineopunctulata

Lerista macropisthopus fusciceps

Lerista micra

Lerista planiventralis decora

Lerista $p$. planiventralis

Lerista praepedita

Lerista uniduo

Lerista varia

Menetia greyii

Menetia surda creswelli

Morethia butleri

Morethia lineoocellata

Morethia obscura

Tiliqua multifasciata

Tiliqua occipitalis

Tiliqua rugosa subsp.

\section{Varanidae}

Varanus brevicauda

Varanus caudolineatus

Varanus eremius

Varanus gouldii

Varanus tristis

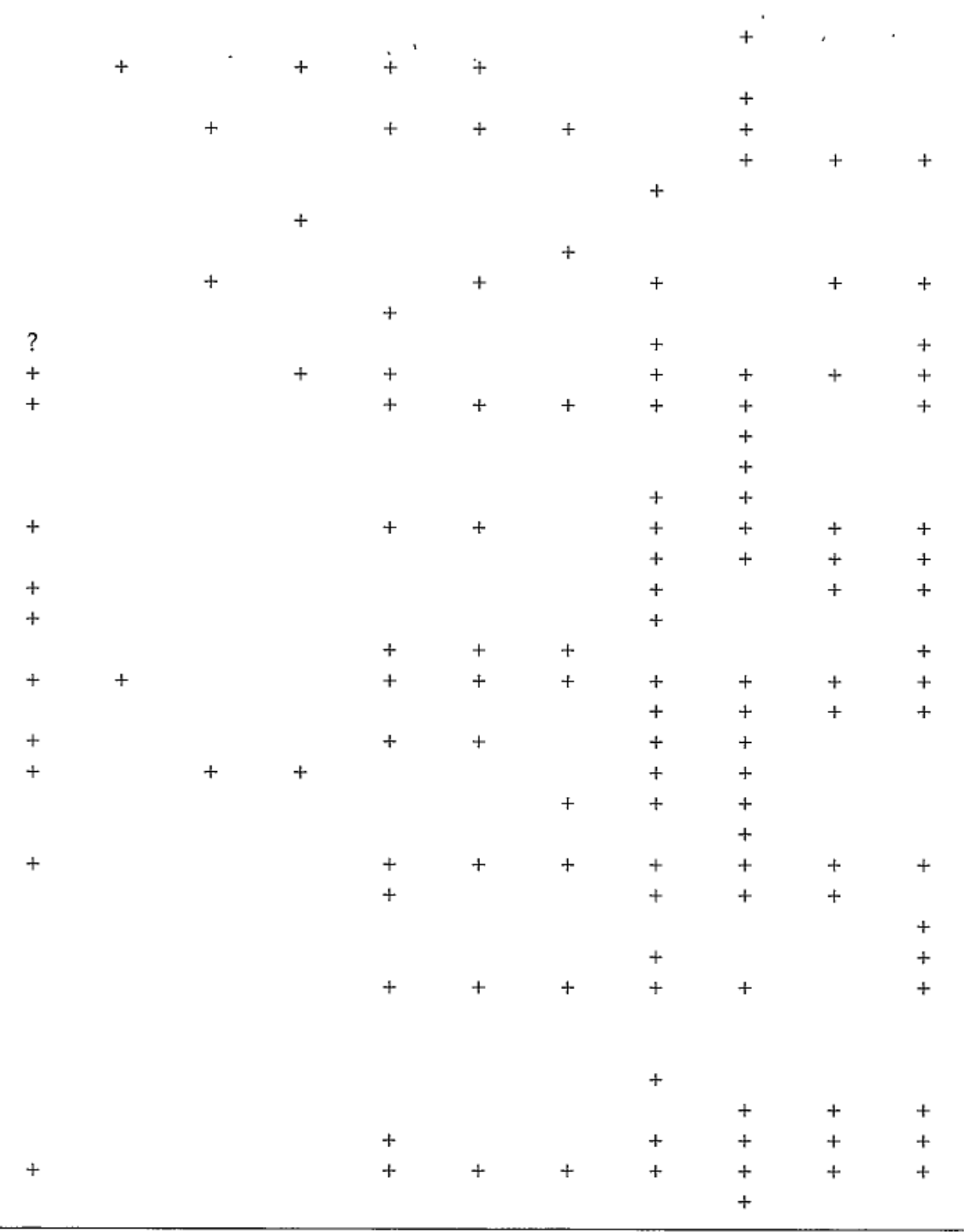

Stockyard Gully and Lancelin, far to the south. No frogs are recorded on Bernier and Dorre Islands.

The numerous small islands located in Useless Loop, between Edel Land and Peron Peninsula, support a total of 16 reptile species (Table 2). Three of the better sampled islands are included in Table 2. Salutation Island, with an area of 162 ha, has a recorded herpetofauna of eight reptiles, all but one of which are recorded from Edel Region. The sole exception, Ctenotus australis, is recorded from Victoria Plateau to the south and Dirk Hartog Island to the north, and might yet be expected to turn up on Edel Land. Baudin Island, with an area of $19 \mathrm{ha}$, also has eight reptile species. Notably, this includes a member of the Menetia greyii group, absent from Edel Region but shared with Peron Region, and a distinctive population of Egernia stokesii (described by Storr (1978) as E. s. aethiops but mtDNA identity with E. s. badia; Hamilton 2003). Three Bays Island, with an area of $5.5 \mathrm{ha}$, has a total of nine recorded species, including a member of the Menetia greyii group and a highly disjunct population of Egernia kingii. The nearest populations of $E$. kingii are in the Houtman Abrolhos (Storr 1978). Its wider distribution extends around the southwest corner of Western Australia, 
east to the Recherche Archipelago, and includes numerous small islands throughout its range. Even smaller islands, with areas of $<5$ ha, support only two or three reptile species. Typically, these include one or more of the gekkonids Gehyra variegata and Heteronotia binoei, and the skink Cryptoblepharus carnabyi. Not surprisingly, these taxa are also common to each of Salutation, Baudin and Three Bays Islands.

\section{DISCUSSION}

Although the May-June 2000 and subsequent surveys significantly extended the species list for Faure Island, a number of apparent absences may yet be due to inadequate sampling. In particular, snakes, goannas and legless lizards are notoriously difficult to sample (Rolfe and McKenzie 2000), the first two groups because they occur in naturally low numbers, and the last-mentioned because many members of the group are highly cryptic and/or exhibit low mobility. In contrast, knowledge of mobile, surface dwelling lizards, such as the larger agamids (Pogona, Ctenophorus spp.) and larger skinks (e.g. Ctenotus spp.) is probably more complete, and absences more likely to be real. In particular, some confidence can be placed in the absence from Faure Island of the dragons Ctenophorus maculatus and C. scutulatus, and the skinks Ctenotus pantherinus, Egernia spp. and Tiliqua spp. Skinks of the genus Lerista are also relatively well-sampled, with a tally of seven species for Faure Island, only three less than on Peron Region. Good coverage in this genus reflects the combined use of pit-trapping and foraging during the survey.

Faure Island was formed shortly before 6500 years ago, during the final stage of the Holocene marine transgression (Semeniuk and Searle 1986). At that time, the recently formed island probably supported something close to the full complement of herpetofauna found on the adjacent landforms of the Peron Region. Divergence of the insular and mainland herpetofaunas since that time potentially occurred through several processes, namely i) local extinction on the island or the mainland habitats; ii) dispersal of taxa onto Peron Region from surrounding habitats, perhaps facilitated by local climatic and environmental adjustments to high sea levels; and iii) dispersal of taxa to Faure Island from a source outside of the Peron Region. In the case of reptiles and frogs, across-water dispersal has probably been relatively insignificant, although several lizard species found in this region are semicommensal and thus prone to anthropogenic translocation (see Appendix).

According to the theory of island biogeography, the biota of continental islands (i.e. those created by sea level rise) undergo a step-wise 'drop out' of taxa towards an 'equilibrium' state where diversity is in accord with island size and habitat complexity (MacArthur and Wilson 1967; Diamond 1975). Kitchener et al. (1980) analysed patterns of reptile diversity on continental islands along the Western Australian coast and concluded that the insular herpetofaunas are approaching or have achieved equilibrium. They also documented a latitudinal effect on diversity, with species richness decreasing to the south. The herpetofaunas of the various Shark Bay islands fit comfortably within this general relationship, suggesting that local extinction has indeed played a significant role in shaping the herpetofauna of these islands.

As reported here, the Faure Island herpetofauna is a subset of that found on the adjacent Peron Region, and such differences that are not due to sampling effort presumably reflect 'drop out' extinctions on the island. As argued earlier, this process appears to have eliminated two of three species of Ctenophorus, several of the larger skinks (Egernia and Tiliqua spp.), and one or more species of Ctenotus. This limited analysis suggests that extinction on Faure Island has resulted in loss of some of the larger reptile taxa, and possibly a reduction in congeneric diversity, especially among medium-sized, surface-dwelling taxa. The present day absence of frogs on both Faure Island and Peron Region might be due to a shared history of extinction. Alternatively, it might reflect an absence of frogs on the annectant land surface during the terminal Pleistocene and early Holocene.

A more comprehensive analysis of the 'drop out' phenomenon is possible through comparison of other insular herpetofaunas in the SBWHA. To do so, we must assume that the disjunct occurrence of a taxon on each of Edel Land and the Cape Cuvier coastal margin (west of Lake Macleod) is evidence of former continuity of range across the now submerged Shark Bay plains. If so, then it may be reasonably inferred that the absence of such a taxon from any of Dirk Hartog, Dorre or Bernier Islands is likely to be due to the 'drop out' effect. Using this criterion, two reptile species (Lerista connivens and Lucasium alboguttatum) appear to have become extinct on all major islands. Five reptiles (Lerista varia, Pogona $m$. minor, Ctenophorus reticulatus, Delma butleri and Pseudonaja nuchalis) were lost from Bernier and Dorre Islands but survive on Dirk Hartog Island. Two species (Lerista elegans and Cyclodomorphus celatus) were lost from Dirk Hartog but survive on Bernier and Dorre Islands. One species (Cryptoblepharus plagiocephalus) was lost from Bernier Island only; and two (Nephrurus levis occidentalis and Lerista praepedita) only from Dorre Island. Other reptile species which might once have occurred on other islands include Menetia surda cresswelli and Egernia multiscutata, both currently restricted to Bernier Island; and 
Brachyurophis $f$. fasciolata, now restricted to Dirk Hartog Island. With the exception of the population of Arenophryne rotunda on Dirk Hartog Island, any original frog fauna has been lost from the other islands of Shark Bay.

While these lists of presumed local extinction events are informative, they are also inherently conservative, since they require the survival of any taxon on both the Cuvier coastal margin and one or both of the Shark Bay peninsulae, all of which are relatively small and narrowly connected areas where local extinction might not be immediately countered by dispersal from surrounding areas. This is especially true in the case of the Cuvier coastal strip, which is in many ways a continental refugium of south-coastal herpetofauna (Aplin et al. unpublished report), bordered to the east by an arid-zone fauna.

An interesting feature of the presumed local extinctions is the lack of obvious bias toward any particular taxonomic or ecological group. All families except varanids, boids, typhlopids and hylid frogs are represented, and there is no clear bias towards larger-bodied taxa or for terrestrial over fossorial species. This observation is in keeping with the conclusions of Kitchener et al. (1980), although their data, based on a larger series of Western Australian islands and mainland conservation reserves, show a slightly enhanced survival of smaller members of any family of lizards, and of gekkotans compared with other groups of lizards. Persistence of relatively large lizards on even very small islands in Shark Bay, for example of Egernia kingii on Three Bays Island (5.5 ha), has already been noted. Indeed, in this particular genus, which shows many such examples of populations persisting on very small Western Australian islands (Ford 1963; Storr 1965), a case might be made for enhanced survival prospects on very small islands, perhaps on account of the absence of many competitors or major predators such as pythons and varanids.

\section{ACKNOWLEDGEMENTS}

We thank AWC (previously known as Paruna Sanctuaries Ltd.) for organizing and providing funding for this survey of Faure Island. We thank J. Forrest, A. Schmitz, T. Reardon and J. Waldock for assistance with the trapping. The Western Australian Museum funded J. Dell in May 2000. K. Aplin and S. Donnellan acknowledge the ongoing support of the Australian National Wildlife Collection, CSIRO, and the South Australian Museum, respectively.

\section{REFERENCES}

Adams, M., Foster, R., Hutchinson, M.N., Hutchinson, R.G. and Donnellan, S.C. (2003). The Australian 'scincid lizard Menetia greyii: a new instance of widespread vertebrate parthenogenesis. Evolution 57: 2619-2627.

Algar, D. and Angus, G.J. (2008). Feasibility study for the eradication of feral cats from Faure Island, Shark Bay, Western Australia. Records of the Western Australian Museum Supplement 75: 71-75.

Aplin, K.P. and Smith, L.A. (2001). Checklist of the frogs and reptiles of Western Australia. Records of the Western Australian Museum Supplement 63: 51-74.

Aplin, K.P., Cowan, M.A. and Adams, M. (unpublished report). Systematics and biogeography of the herpetofauna of the Carnarvon Basin region of Western Australia.

Badham, J.A. (1976). The Amphibolurus barbata species group (Lacertilia: Agamidae). Australian Journal of Zoology 24: 423-443.

Beard, J.S. (1976). The Vegetation of the Murchison Area. Vegetation Survey of Western Australia. 1:1,000,000 Vegetation Series. Explanatory Notes to Sheet 6. Murchison. University of Western Australia Press, Crawley, WA.

Beard, J.S. (1980). A new phyogeographic map of Western Australia. Western Australian Herbarium Research Notes 3: 37-58.

Burbidge, A.H., McKenzie, N.L. and Harvey, M.S. (2000). A biogeographic survey of the southern Carnarvon Basin, Western Australia: background and methods. Records of the Western Australian Museum Supplement 61: 1-12.

Diamond, J.M. (1975). The island dilemma: lessons for the design of natural reserves. Biological Conservation 7: 129-146.

Douglas, A.M. and Ride, W.D.L. (1962). Reptiles. (pp. 113-119). In: Ride, W.D.L., Mees, G.F., Douglas, A.M., Royce, R.D. and Tyndale-Biscoe, C.H. (eds) The results of an expedition to Bernier and Dorre Islands, Shark Bay, Western Australia in July, 1959. Western Australian Fisheries and Department of Fauna Bulletin Volume 2.

Ford, J. (1963). The distribution and variation of the skinks Egernia pulchra and E. bos in Western Australia. Western Australian Naturalist 9: 25-28.

Hamilton, Z. (2003). Marooned lizards: variation in isolated and fragmented populations of Egernia stokesii. Honours Thesis. University of Western Australia, Crawley, WA.

Hammond, T.J. (1998). Geographic variation in the scincid species Lerista lineopunctulata. Honours Thesis. University of Western Australia, Perth.

Han, D., Zhou, K. and Bauer, A.M. (2004). Phylogenetic relationships among gekkotan lizards inferred from C-mos nuclear DNA seequences and a new classification of the Gekkota. Biological Journal of the Linnean Society 83: 353-368.

Hocking, R.M., Williams, S.J., Moors, H.T. and Graaff, W.J.E. van der (1987). Geology of the Carnarvon Basin, Western Australia. Western Australia Geological Survey, Bulletin 133, 289 pp.

Keighery, G. and Muir, W. (2008). Vegetation and vascular flora of Faure Island, Shark Bay, Western Australia. Records of the Western Australian Museum Supplement 75: 11-19. 
Keighery, G.J., Gibson, S., Lyons, M.N. and Burbidge, A.H. (2000). Flora and vegetation of the southern Carnarvon Basin, Western Australia. Records of the Western Australian Museum Supplement 61: 77-154.

Kendrick, G.W., Wyrwoll, K.-H. and Szabo, B.J. (1991). Pliocene-Pleistocene coastal events and history along the western margin of Australia. Quaternary Science Reviews 10: 419-439.

Kendrick, P. (1991). The phylogenetics and comparative ecology of Lerista Bell, 1833; patterns of evolution in a genus of sand-swimming skinks. Ph.D. Thesis. University of Western Australia, Perth, WA.

Kitchener, D.J., Chapman, A., Dell, J., Muir, B.G. and Palmer, M. (1980). Lizard assemblage and reserve size and structure in the Western Australian wheatbelt some implications for conservation. Biological Conservation 17: 25-62.

MacArthur, R.H. and Wilson, E.O. (1967). The Theory of Island Biogeography. Princeton University Press, Princeton, New Jersey, U.S.A.

McKenzie, N.I., Rolfe, J.K., Aplin, K.P., Cowan, M.A. and Smith, L.A. (2000). Herpetofauna of the southern Carnarvon Basin, Western Australia. Records of the Western Australian Museum Supplement 61: 335360.

Moritz, C. (1983). Natural parthenogenesis in the endemic Australian lizard, Heteronotia binoei (Gekkonidae). Science 220: 735-737.

Moritz, C., Donnellan, S., Adams, M. and Baverstock, P. (1989). The origin and evolution of parthenogenesis in Heteronotia binoei: extensive genetic diversity among parthenogens. Evolution 43: 994-1003.

Moritz, C., Adams, M., Donnellan, S., and Baverstock, P. (1990). The origin and evolution of parthenogenesis in Heteronotia binoei: genetic diversity among bisexual populations. Copiea 1990: 333-348

Pepper, M., Doughty, P. and Keogh, J.S. (2006). Molecular phylogeny and phylogeography of the Australian Diplodactylus stenodactylus (Gekkota; Reptilia) species-group based on mitochondrial and nuclear genes reveals an ancient split between Pilbara and non-Pilbara $D$. stenodactylus. Molecular Phylogenetics and Evolution 41: 539-555

Rolfe, J.K. and McKenzie, N.I. (2000). Comparison of methods used to capture herpetofauna: an example from the Carnarvon Basin. Records of the Western Australian Museum Supplement 61: 361-370.

Schmitz, A. and Richards, J.D. (2008). A survey of the terrestrial vertebrates of Faure Island, Shark Bay, Western Australia. Records of the Western Australian Museum Supplement 75: 33-37.

Semeniuk, V. and Searle, D.J. (1986). Variability in Holocene sea level history along the southwestern coast of Australia - evidence for the effect of significant local tectonism. Marine Geology 72: 47-58.

Smith, L.A. and Adams, M. (2007). Revision of the Lerista muelleri species-group (Lacertilia: Scincidae) in Western Australia, with a redescription of L. muelleri (Fischer, 1881) and the description of nine new species. Records of the Western Australian Museum 23: 309-357.
Storr, G.M. (1965). The physiography, vegetation and vertebrate fauna of the Wallabi Group, Houtman Abrolhos. Journal of the Royal Society of Western Australia 48: 1-14.

Storr, G.M. (1966). The Amphibolurus reticulatus speciesgroup (Lacertilia, Agamidae) in Western Australia. Journal of the Royal Society of Western Australia 49: 17-25.

Storr, G.M. (1967). The genus Vermicella (Serpentes: Elapidae) in Western Australia and the Northern Territory. Journal of the Royal Society of Western Australia 50: 80-92.

Storr, G.M. (1972). The genus Lerista (Lacertilia: Scincidae) in Western Australia. Journal of the Royal Society of Western Australia 54: 59-75.

Storr, G.M. (1978). Taxonomic notes on the reptiles of the Shark Bay region, Western Australia. Records of the Western Australian Museum 6: 303-318.

Storr, G.M. (1979). Revisionary notes on the genus Vermicella (Serpentes: Elapidae). Records of the Western Australian Museum 8: 75-79.

Storr, G.M. (1982). Revision of the bearded dragons (Lacertilia: Agamidae) of Western Australia with notes on the dismemberment of the genus Amphibolorus. Records of the Western Australian Museum 10: 199-214.

Storr, G.M. (1991). Partial revision of the Lerista macropisthopus group (Lacertilia: Scincidae). Records of the Western Australian Museum 15: 149-161.

Storr, G.M. and Harold, G. (1978). Herpetofauna of the Shark Bay region, Western Australia. Records of the Western Australian Museum 6: 449-467.

Storr, G.M. and Harold, G. (1980). Herpetofauna of the Zuytdorp Coast and hinterland, Western Australia. Records of the Western Australian Museum 8: 359_ 375.

Storr, G.M. and Harold, G. (1984). Herpetofauna of the Lake Macleod region, Western Australia. Records of the Western Australian Museum 11: 173-189.

Storr, G.M., Smith, L.A. and Johnstone, R.E. (1990). Lizards of Western Australia 3, Geckos and Pygopods. Western Australian Museum, Perth, WA.

Thackway, R. and Cresswell, I.D. (1995). An Interim Biogeographic Regionalisation of Australia. Australian Nature Conservation Agency, Canberra, ACT.

Witten, G.J. (1994a). Taxonomy of Pogona (Reptilia: Lacertilia: Agamidae). Memoirs of the Queensland Museum 37: 329-343.

Witten, G.J. (1994b). Relative growth in Pogona (Reptilia: Lacertilia: Agamidae). Memoirs of the Queensland Museum 37: 345-356.

Wyrwoll, K. -H., Stoneman, T., Elliot, G. and Sandercock, P. (2000). Geoecological setting of the Carnarvon Basin, Western Australia: geology, geomorphology and soils of selected sites. Records of the Western Australian Museum Supplement 61: 29-75. 


\section{APPENDIX}

\section{TAXONOMIC AND DISTRIBUTIONAL NOTES ON FAURE ISLAND REPTILES}

\section{NOMENCLATURE}

The taxonomic arrangement follows usage in Aplin and Smith (2001), except where more recent work supports an alternative arrangement. At the higher level, the major change is recognition of three families within 'Gekkonidae' - true Gekkonidae, Carphodactylidae and Diplodactylidae (following Han et al. 2004).

\section{FAMILY ELAPIDAE}

\section{Simoselaps littoralis (Storr, 1968)}

This species was collected by W.H. Butler in 1959 and again by the survey team in 2000 when two were trapped in site 4 and a dead specimen located on a birrida. It was also recorded in feral cat stomachs in September 2000 (Algar and Angus 2008).

The wider distribution of $S$. littoralis extends from Cervantes in the south, north to North West Cape. In the Carnarvon Basin biogeographic region it is distributed along the coastal strip, including the Edel and Peron Regions and adjacent parts of the Victoria Plateau, Dirk Hartog, Dorre and Bernier Islands, and the vicinity of Cape Cuvier and Gnaraloo in the north.

Storr (1967) noted geographic variation within $S$. littoralis. Specimens from northern areas (Point Cloates to Shark Bay) differed from those from south of Jurien Bay in having a lower number of encircling rings on the body and tail; a longer nuchal blotch; fewer ventral and subcaudal scales; and a relatively longer tail. Aplin et al. (unpublished report) examined geographic variation in these and other features of $S$. littoralis, based on a far larger sample than was available to Storr. Their preliminary results indicate that $S$. littoralis appears to consist of two closely related but, in all likelihood, distinct taxa that can be distinguished on a variety of scalation and pattern characteristics. These are distributed roughly north and south of Shark Bay, as indicated by Storr (1979). However, in the vicinity of Shark Bay itself, the distinction between the two 'morphs' becomes blurred, with many intermediates and atypical admixtures of characters. Whether this represents a zone of hybridisation or alternatively, an area where the diversity of contrasting habitats results in strong patterns of differential selection on traits, cannot be decided without some analysis of molecular genetic markers.

\section{FAMILY BOIDAE}

Antaresia stimsoni stimsoni (Smith, 1981)

This species was encountered on Faure Island by the survey team in 2000. Individuals were located in old buildings including the shearing shed and buildings around the homestead.

Stimson's python is widespread throughout the Carnarvon Basin biogeographic region. Collection records suggest that it is more abundant in the northern half of the region and on each of Dirk Hartog; Bernier and Dorre Islands, with comparatively few records from Peron and the Victoria Plateau. A specimen from Denham was examined at the Western Australian Museum in 1992, but was returned for release on Peron Peninsula.

\section{FAMILY AGAMIDAE}

\section{Ctenophorus reticulatus (Gray, 1845)}

This species is virtually ubiquitous throughout the Carnarvon Basin biogeographic region and was commonly observed on Faure Island. Storr (1966) suggested a preference for heavy, loamy soils. However, its pattern of distribution on major landforms suggests a preference for more sandy substrates than those frequented by its close relative C. nuchalis.

A specimen collected by W.H. Butler was located "near burrow under dead mangroves" (R13127; notes on label). Specimens in 2000 were recorded on birridas.

\section{Pogona minor (Sternfeld, 1919)}

This species is tentatively included on the basis of a sight record at the northern end of Faure Island by S. Donnellan. The specimen was viewed only briefly before escaping under a large Acacia shrub, but it appeared to be larger than the common Ctenophorus reticulatus and its colour and pattern were consistent with that of Pogona minor, the only other large scansorial dragon species recorded from the region.

The taxonomy of Western Australian Pogona remains unresolved. Badham (1976) identified the southwestern and near-coastal populations north to North West Cape as P. minimus, those of the Murchison, Gascoyne and southern Pilbara regions as $P$. minor, and those of the northern Pilbara as $P$. mitchelli. Possible hybrids or intergrades were noted along the boundaries between each of minimus and minor, and minor and mitchelli. Storr (1982) treated all of these populations as subspecies of $P$. minor, and restricted minimus to the Abrolhos Islands. He postulated the presence of a narrow hybrid zone to explain the apparent intergradation between minor and mitchelli. $\mathrm{He}$ also noted consistent geographic variation in the colour of the oral mucosa in $P$. m. minor (yellow in the south; 
changing to white, north of Kalbarri). Witten's (1994a,b) morphometric analysis supported Storr's impressions.

Carnarvon Basin region specimens appear relatively uniform in both body proportions and details of spination. This observation is consistent with Storr's (1982) interpretation and his nomenclature is followed here. A detailed genetic and morphometric investigation of the group is currently underway by Jane Melville (Museum Victoria).

\section{FAMILY GEKKONIDAE}

Gehyra variegata (Duméril and Bibron, 1836)

This species is virtually ubiquitous in the Carnarvon Basin region and is recorded from all major and several of the smaller islands in Shark Bay, including Faure Island. Substantial morphological and chromosomal variation within Carnarvon Basin populations of $G$. variegata suggests that several distinct species occur in this area. No attempt has been made to divide this sample, pending some genetic insight into the broader problem.

W.H. Butler collected a series of this species on Faure Island "in dead mangroves" (R98204-98210; notes on label). In 2000 it was recorded in dead stumps at site 3 and in February was caught at sites $1,2,3,4,5$, and 6 .

\section{Heteronotia binoei (Gray, 1845)}

Bynoe's gecko is ubiquitous through the study area. It is present on all major and many minor islands in Shark Bay. W.H. Butler collected two specimens on Faure Island "mangroves" (R7892278923; notes on label). G. Harold obtained specimens from two habitats: "mid-dense $S$. longifolius on white sandy beach (R103983; notes on label) and "mid-dense $S$. longifolius, sparse low shrubs, very sparse samphire on pink sand" (R103938; notes on label). Specimens in 2000 were trapped at sites 1,2 and 5 and located under iron at the bore and under limestone rocks on cliff near site 4 .

Work by Moritz and others (Moritz 1983; Moritz et al. 1989, 1990) revealed a complex of chromosomally and genetically distinct, diploid sexually reproducing populations within $H$. binoei, among which are interspersed various triploid parthenogenetic populations of hybrid origin. The various parental taxa are weakly differentiated genetically and have largely non-overlapping distributions (Moritz et al. 1990); they probably represent a complex of six or more weakly differentiated species.

Two main groups of sexually reproducing populations are represented in Western Australia. In the Carnarvon Basin area, one group has been recorded from the Victoria and Carbla Plateaus, north to Wooramel. The second group is mainly found in the arid centre of Western Australia and the Northern Territory, extending west to Nanutarra, but with an outlying population at Carrarang. Parthenogenetic populations are known from several localities within the Carnarvon Basin region, most notably Wooramel and near Lake Macleod (Moritz et al. 1989). Precise identification of Faure Island specimens will require genetic analyses.

\section{FAMILY CARPHODACTYLIDAE}

\section{Nephrurus levis occidentalis De Vis, 1886}

This species is widely distributed in the Carnarvon Basin region but is probably most abundant in the near coastal areas.

G. Harold obtained a specimen on Faure Island in "mid-dense S. longifolius, sparse low shrubs, very sparse samphire on pink sand" (R103936; notes on label). Specimens in 2000 were trapped at sites 4 , 10.

\section{FAMILY DIPLODACTYLIDAE}

\section{Diplodactylus pulcher (Steindachner, 1870)}

This taxon is widespread in the Carnarvon Basin biogeographic region but is seemingly absent from Edel Region and from much of the Carnarvon Coastal Plain. It has been collected once only on Faure Island, by G. Harold in "low, open Acacia shrubland on red sand" (R103937; notes on label). An additional individual was captured and photographed in October 2005 by AWC staff.

\section{Lucasium squarrosum (Kluge, 1962)}

This species is also widespread in the Carnarvon Basin biogeographic region but with no records from Edel Region or Peron Peninsula. It was collected on Faure Island by G. Harold in 1989 and again by the survey team in 2000. Harold's specimen was obtained in "eaten out Acacia shrubland on red sand (R103940; notes on label). This species was trapped at site 10 in 2000.

The Carnarvon Basin population is probably disjunct from other populations centred on the semiarid southern interior and the headwaters of the Ashburton River in the Pilbara. Storr et al. (1990) noted morphological differences between the various populations. Pepper et al. (2006) reported molecular differentiation between the Carnarvon Basin and southern interior populations. Their study included the recently collected specimen (R141462) from Faure Island.

\section{Strophurus strophurus (Duméril and Bibron, 1836)}

This species is widespread in the Carnarvon Basin region. Its wider distribution includes the central and southern arid zone of Western Australia, north to North West Cape and the Pilbara Region, and 
inland to the Warburton Range. It was recorded in Acacia shrubland during head torching in May 2000.

Storr et al. (1990) noted geographic variation in the colour of the dermis around the eye and between the tail segments, which is usually orange or yellow, but may be pure white in the southwestern part of the species' range. The pigment is rapidly lost in preservative. The majority of specimens collected in the Carnarvon Basin region survey had distinctly yellow eye rings and tail skin but with occasional white examples at a number of sites.

\section{FAMILY SCINCIDAE (Skinks)}

\section{Cryptoblepharus sp.}

Cryptoblepharus plagiocephalus was tentatively recorded from Faure Island on the basis of a sight record by J. Dell on the homestead building in May-June 2000. However, this species is morphologically very similar to $C$. carnabyi and, without a voucher specimen, we cannot be certain as to the identity of the Faure Island Cryptoblepharus. In the wider Carnarvon Basin region, $C$. plagiocephalus is recorded from sites in Edel Region and the adjacent western margin of the Victoria Plateau, and also on Dirk Hartog and Dorre Islands. One of two distinct forms of $C$. carnabyi found in the Carnarvon Basin biogeographic region is recorded from Peron Region.

\section{Ctenotus fallens Storr, 1976}

This species was recorded by G. Harold in 1989 and again by the 2000 survey team. Harold's specimen was collected from "mid-dense $S$. longifolius, sparse low shrubs, very sparse samphire on pink sand" (R103935; notes on label). It was widespread and abundant on Faure Island in 2000 and 2003 and trapped at sites 1, 2, 3, 4, 5, 6, 7, and 9.

The species is widely distributed across the Edel and Peron Regions and the adjacent southwest part of Victoria Plateau, extending onto Peron Peninsula.

\section{Ctenotus schomburgkii (Peters, 1863)}

This species was not recorded until July 2005 when three were pit-trapped at site 10 and an additional freshly dead individual was photographed on a track in red sand.

Ctenotus schomburgkii is widespread across the inland part of the Carnarvon Basin biogeographic region and it also occurs on both Peron Peninsula and Edel Land. These populations are highly variable in appearance and it is possible that more than one taxon is represented (Aplin et al., unpublished report). Rather surprisingly, no member of this group is recorded on any of the other large islands in Shark Bay.

\section{Eremiascincus sp.}

An Eremiascincus sp. was recorded in a cat stomach by Algar and Angus (2008). This represents the only evidence for a member of this genus on Faure Island.

Genetic studies underway by S. Donnellan and P. Doughty indicates great complexity within the genus Eremiascincus and there is little value at present in attempting a species identification. Previous samples from localities on Peron Peninsula and on the Carnarvon Coastal Plain have been identified as $E$. richardsonii. Interestingly enough, this genus is not represented on any of the other islands in Shark Bay.

\section{Lerista connivens (Storr, 1972)}

This species was recorded by G. Harold in 1989 and again by the 2000 survey team. Harold's specimen was collected from "mid-dense Spinifex longifolius on white sandy beach" (R103941; notes on label). Specimen in 2000 was trapped at site 9.

The wider range of this species encompasses most of the Carnarvon Basin region, including both coastal landforms and inland depositional and erosional surfaces.

\section{Lerista elegans (Gray, 1845)}

This species is widely distributed and abundant in the Carnarvon Basin region with numerous records from the adjacent Edel and Peron Regions. On Faure Island G. Harold collected two specimens in "mid-dense Spinifex longifolius on white sandy beach" (R103987-103988; notes on label). Specimens in 2000 were trapped at sites 1 and 5 .

Lerista elegans shows considerable variation in patterning within the Carnarvon Basin area, especially in the degree of 'brightness', but there appears to be little geographic structure to the observed variation. A pilot genetic study of representative specimens showed low levels of genetic differentiation between regions within the Carnarvon Basin, compatible with the presence of a single species (Aplin et al., unpublished report).

\section{Lerista lineopunctulata (Duméril and Bibron, 1839)}

Faure Island specimens obtained by G. Harold came from "mid-dense Spinifex longifolius on white sandy beach" (R103939; notes on label). Habitat of the 2000 specimen was not recorded.

Lerista lineopunctulata is best regarded as a 'complex' of closely related forms with abutting or narrowly overlapping distributions. Members of this complex are widely distributed along the west coast, from the Swan River to North West Cape.

Storr (1972) reported differences between southern and northern populations in forelimb development (style vs groove), pedal digit number (2 vs 1), body patterning (dashed vs plain), head colouration (pale vs dark) and number of nuchal scales. However, specimens from "the intervening 
region" were stated to be "variously intermediate" with "no concord between limb development and colour type". Storr examined a total of 62 specimens; since his time the holdings of the Western Australian Museum for this species has grown to more than 560 specimens, over 100 of which were obtained during the Carnarvon Basin Biological Survey.

Preliminary study of this greatly expanded series by Aplin et al. (unpublished report) revealed very strong geographic patterning in both the degree of limb reduction and body elongation. However, a pilot study of Carnarvon Basin populations failed to identify any genetic differences between one-toed and two-toed populations. A geographically broader genetic study of $L$. lineopunctulata undertaken by Hammond (1998) also found low levels of genetic divergence between populations.

\section{Lerista macropisthopus fusciceps Storr, 1991}

This species is widespread through the Carnarvon Basin region; represented on all surfaces except Edel Land and the adjacent western margin of Victoria Plateau and Peron Region. It is present on Peron Peninsula but absent from all major and minor islands in Shark Bay except Faure Island where it remained undetected until the survey in 2000. Habitat of the 2000 specimen was not recorded.

Storr (1991) noted considerable variation in supraciliary formula in $L$. $m$. fusciceps, with varying degrees of fusion of anterior supraciliaries to the adjacent supraocular scales. This showed some geographic basis, most notably in the high frequency of the ' $0+3$ ' variant at Yardie Creek, North West Cape. Aplin et al. (unpublished report) found no evidence for differing frequencies of supraciliary variants across the Carnarvon Basin region.

\section{The 'Lerista muelleri group'}

The Lerista muelleri group is a complex of 10 or more weakly differentiated species, four of which are represented in the Carnarvon Basin biogeographic region (Aplin et al., unpublished report; Smith and Adams 2007). No member of the group is present on Edel Land, on the western side of Lake Macleod, or on any of Dirk Hartog, Bernier or Dorre Islands. Peron Peninsula supports a population of L. micra Smith and Adams (2007; 'Lerista muelleri B' of Aplin et al., unpublished report), which is the most widely distributed member of the group in this region. Kendrick's (1991) ecological observations for this group pertain to $L$. micra. He noted a preference for the surface and outer margins of litter beds, and a diet consisting primarily of termites.

Lerista micra was collected on Faure Island for the first time during the 2000 survey but detail of habitat was not recorded.

\section{Lerista planiventralis decora (Storr, 1978)}

This taxon was collected on Faure Island for the first time during the 2000 survey when specimens were trapped at site 10 and again in 2002 when trapped at sites 1, 2, 3, 4 and 7 .

The subspecies L. $p$. decora is found on Peron Peninsula. It extends south through Hamelin and the Zuytdorp area to Badgingarra on the lower west coast and inland to the sand plains of Yuna and Watheroo. The subspecies L. p. planiventralis is found on Edel Land and Dirk Hartog, Dorre and Bernier Islands, along a coastal strip of the northern Carnarvon Basin south to Cape Cuvier, and inland to Kennedy Range. The typical form is replaced in the far north at Barradale Roadhouse and near Onslow by L. p. maryani. The various subspecies are well-differentiated morphologically. However, Kendrick (1991) found no genetic differences between samples of the typical form and populations of $L$. planiventralis decora from the Hamelin area. He also found no evidence of genetic differentiation between samples of $L$. $p$. planiventralis from the northern and southern parts of its range.

\section{Lerista praepedita (Boulenger, 1887)}

This taxon was collected on Faure Island for the first time during the 2000 survey when specimens were trapped at site 7 .

It is widely distributed through the Edel and Peron Regions and the adjacent parts of the Victoria Plateua and Carbla Plateau, north to the Carnarvon Coastal Plain and the vicinity of Lake Macleod. Its broader distribution extends from Mandurah in the south to the tip of North West Cape.

Examination of specimens from the Carnarvon Basin region by Aplin et al. (unpublished report) revealed a significant difference in paravertebral numbers between the populations with contrasting supraocular patterns (higher in all populations with two supraoculars) and a correlated difference in nuchal scale counts (lower in these populations): Although these correlated morphological differences suggest the presence of a sibling species pair within L. praepedita, genetic analysis revealed low levels of differentiation.

\section{Lerista varia Storr, 1986}

This taxon was collected on Faure Island by $\mathrm{G}$. Harold and again during the 2000 survey. Harold's specimens were obtained from "mid-dense Spinifex longifolius with sparse low shrubs and samphire on pink sand" (R104251-104252; notes on label); and from "mid-dense Spinifex longifolius on white sandy beach" (R104253; notes on label). Habitat of the 2000 specimen was not recorded.

This species has a disjunct distribution in the Carnarvon Basin biogeographic region, with populations in Edel Region and adjacent parts of the Victoria Plateau, on Peron Peninsula north of 
Lharidon Bight, on Dirk Hartog Island, and at Cape Cuvier in Macleod Region. It appears to be strictly confined to sandy soils.

\section{The 'Menetia greyii group'}

Members of this group are more or less ubiquitous throughout the Carnarvon Basin biogeographic region. However, morphological and genetic analyses of Menetia from this region and elsewhere in Australia revealed a number of distinct sexually reproducing taxa, together with various regional parthenogenetic populations of hybrid origin (Aplin et al., unpublished report; Adams et al. 2003). Three sexually reproducing taxa are represented in the Carnarvon Basin biogeographic region. Genetic identification of Faure Island specimens is required to establish their identity.

The taxon was undetected on Faure Island prior to the survey in 2000 when a specimen was trapped at site 2 .

\section{Morethia lineoocellata (Duméril and Bibron, 1839)}

This species is widely distributed through the Carnarvon Basin region, although most specimens come from near coastal localities. It appears to be particularly abundant on Edel Land, on Dirk Hartog, Dorre and Bernier Islands, and at Cape Cuvier. It was collected on Faure Island by $\mathrm{K}$. Morris in 1989 and recorded as abundant and widespread by the survey team in 2000 when specimens were trapped at sites 1, 3, 6, 7, 9, 10 .

The wider distribution of $M$. lineoocellata extends from the tip of North West Cape south to Cape Leeuwin. Across its range, $M$. lineoocellata is highly variable in both the style and intensity of patterning. Classic 'ocellated' individuals are often found together with less intensely spotted individuals that resemble sympatric $M$. obscura, while others are darkly pigmented, almost melanistic, both dorsally and ventrally. Within the Carnarvon Basin region, pale, brightly patterned and dark individuals occur in approximately equal numbers and both forms are generally present within any given area. At localities on Peron Peninsula and on Mardathuna Station, inland of Lake Macleod, dark individuals predominate, while at Cape Cuvier the reverse is true. In general, the 'dark' morph appears to be more abundant on the red sand and inland surfaces, the 'patterned' morph more so on pale coastal sands. A pilot genetic analysis failed to identify any significant difference between the two forms of $M$. lineoocellata in the Carnarvon Basin biogeographic region (Aplin et al., unpublished report).

\section{FAMILY VARANIDAE (Monitors)}

\section{Varanus gouldii (Gray, 1838)}

This species was listed as occurring on Faure Island by Douglas and Ride (1962) and Storr and Harold (1990), presumably based on information from W.H. Butler, but there are no associated voucher specimens. It was not observed by the survey team in 2000. In September 2000 Algar and Angus (2008) recorded it as the principal dietary item of trapped feral cats, indicating it was then reasonably common on Faure Island. Since 2000 this species has frequently been sighted, trapped and photographed on Faure Island by AWC staff and recorded feeding on reintroduced and radiocollared Shark Bay Mouse (Trish Gardner, pers. comm.).

Varanus gouldii is widely distributed within the Carnarvon Basin biogeographic region and is present on Dirk Hartog, Dorre and Bernier Islands. 